\title{
Estimated Status of Quantum Losses other than Consumption under Seed, Feed and Wastage: Farm Levels Study of Pulse (Lentil) in Bihar
}

\author{
Amalendu Kumar ${ }^{1} *$ and R.S. Singh ${ }^{2}$
}

${ }^{1}$ Department of Agricultural Economics, TCA Dholi, Muzaffarpur, India

${ }^{2}$ Dr. Rajendra Prasad Central Agricultural University, Bihar, India

*Corresponding author

\section{A B S T R A C T}

\section{Keywords}

Consumption, Seed, Feed, Wastage, Lentil, Bihar

\section{Article Info}

Accepted:

15 February 2019

Available Online:

10 March 2019
The study conducted in the state of Bihar has examined, the quantity losses other than consumption for lentil crop amongst different farm size groups. It has found that at overall level 46.91 percent of the total lentil crop produced was available as marketable surplus. At the overall level study finds about 19.56 percent of the total lentil produce goes wastage as seed, feed, and wastage however only 80.44 percent available for consumption purpose. In the backward state like Bihar where a significant percentage of population under malnutrition and hardly get recommended level of protein to the people. If the wastage ratio managed addition of pulse quantum in food basket may be increased. The government needs to develop appropriate strategies for reducing the wastages under seed, feed and post losses. The net availability of crop may be increases through proper management of losses under seed, feed and wastage.

\section{Introduction}

\section{Rationals}

India is the largest producer and consumer of pulses in the world accounting for 33.0 percent of the area and 22.0 percent of the production. Amongst the pulses producing countries, India is the largest share holder in pulse trade as producer $\mathrm{s}$, consumer and importers. In the world, pulses is grown under 70.0 million hectares of land and producing above 45.0 million tons. The pulses area in India was increasing from 1950-51 to 201415. During 1950-51 the total area under the crop was 19.09 million hectares which is increased 25.59 million hectares in 2014-15. During the same referred period the production was increased from 8.41 million tons in 1951 to 18.60 million tons in 2014-15 and productivity increased from 441 kilogram per hectare to 785 kilogram per hectare. In same period the population of the country increases from 36.11 crores to 121.60 crores. Since 1951 to 2011 the urban population increased from 18.0 percent to 31.20 percent In the country. As a result of rapid increase in the population, the availability of pulses per capita was declined from 60.70 gram per day in 1950-51 to 35 gram per day in 2015-16 and 
continuous widening the gap between the demand and supply of pulses. In the urban areas diet shift from cereal donated diet to protein due to nutritional awareness and improvement in economic conditions. In the past year due to serious efforts taken by the government production of the crop reached above 23.0 million tons (2017-18) (Ahuja and Tyagi, 2000).

The state of Bihar is also one of the potential pulses producing and consuming states in the country. The state contributes about 2.35 percent of total area and 3.06pecent total production of pulses in the country. This crop occupied about 9.29 percent of the gross cropped area and produces about 542.70 thousand tons in (2013-14). In the state pulses are grown in almost three season i.e. kharif, rabi and summer.

As per The latest available data on pulses indicates about 634.80 thousand tons of production of which rabi pulses contributes 466.10 thousand tones of production followed by summer 92.10 thousand tones and khrif 76.60 thousand tones. Amongst the pulses, lentil production was 183.30thousand tones (28.87\%), kheshari 83.80 thousand tones (13.20\%), gram 86.20 thousand tones $(13.58 \%)$ and pea only 19.3 thousand tons (3.04\%) and under rabi season. In kharif season the major pulses are arhar 7.20 thousand tones (1.13\%), urd 12.20 thousand tones $(1.92 \%)$, moong 7.20 thousand tones $(1.13 \%)$ and kulthi 7.80 thousand tones $(1.22 \%)$. The share of summer moong in the production was 92.10 thousand tones $(14.50 \%)$. The other pulses under rabi, kharif and summer contributes about $21.41 \%$ (Ramaswamy and Selveraj, 2002).

The contribution of pulses in food grains as per the data 2015-16 it was estimated 8.25 percent and production about 3.93 percent. The average productivity of pulses crop was $824 \mathrm{~kg}$ per hectare in between 2012-13 to
2014-15. The existing yield of pulses like lentil $875 \mathrm{~kg} / \mathrm{ha}$, pigeonpea $1370 \mathrm{~kg} / \mathrm{ha}$, urad $650 \mathrm{~kg} / \mathrm{ha}$, moong 570k/ha, chickpea 950 $\mathrm{kg} / \mathrm{ha}$ and lathyrus $850 \mathrm{~kg} / \mathrm{ha}$ which is just half of the potential yield and there is scope for increase in productivity in the state. As per the recommendation of WHO for a adult around 2 to $2.5 \mathrm{~kg}$ per month requirement of pulses but at present it is available only 700 gram per month. However at the national level the availability was estimate $1.25 \mathrm{~kg} / \mathrm{month}$ which is below the recommended level. This is mainly due to marginal increase in the production of pulses and rapidly increases in population. The continuous increasing demand of pulses may be met out by fast technological change because of the limited option to expand the land area under pulses and through proper management of seed feed and wastage ratios. As per Remaswamy and Selvaraj (2002) they found that out of the total supply of pulses for domestic purpose as food it accounted nearly 82 percent. Out of the total wastage, seed accounts for (6\%) feed (9\%) and wastage $(3 \%)$. The estimates were nearly 4 to 5 lakh tons of pulses wasted annually in the country. An estimate made by raddy in 2004, about 18.50 million tons of pulses producing annually by the country and domestic consumption estimated around 22. Million tons per annum a short of 4.5 million ton of pulses and was filled up by imported pulses. In the recent years the production level goes up to 22.0 million tons but country facing deficit of pulses (Gill, 2000; Ojha, 1984).

In the light of the above facts, this is important to estimates of seed, feed and wastage ratio for major pulses crop (lentil) and their availability for human consumption as a broad objective. The study is the outcome of a pilot study on estimation of seed, feed and wastage ratio for major food grain which was assigned by ministry of agriculture, government of India in the year 2005. The method for data collection was prepared by Dr. H.V.L Bathla of Indian institute of agriculture statistics research, New 
Delhi and co-ordinate by Dr. R.S. Desh pande, professor and head, ADRT Unit, institute of social and economic change, Bangalore. Author was project leader of the study.

\section{Status}

It was observed through past studies that up to the year 2005-06, the total food grain production and estimated requirements a marked deficit of 20.31 lakh tones which was 15 percent lower than the demand in the state of bihar. The seed rate of lentil crop during the same period was found not a definite trend which was either increases or decreases. The state government had been prescribing seed rate for lentil between $25 \mathrm{~kg}$ to $40 \mathrm{~kg}$ per hectare across the state but it could be observed that majority of the farmers did not follow their recommended seed, they used as per the availability and capability. Hence it is not possible at the state level to exactly estimate quantum of seed ratio of the crop. In the state as per the latest livestock census nearly 16 percent increase of livestock in last five year period of the survey. As per the department of animal husbandry, the recommended feed quantities for livestock were 10 quintals per animal per annum. This lead to a requirement of about 25000 tons of feed in the referred period and will gone up increasing in future due to increasing trends of livestock.

The minimum recommended requirement of poultry feed was $5 \mathrm{~kg}$ per annum per poultry bird and about 4330 tones feed required for the poultry. On an average 100 percent increase in number of poultry during the last five year and feed demand naturally increases double. As regard wastage ratios of food grains in the form of losses from harvesting to consuming no concrete data has been found. However the rough estimates in this regard reveals about 15 to 20 percent losses in case of major cereals. It has been suggested by several estimates by Dada Bhai, Naroji, (1868) Shah and Khambatta (1921), VKRV Rao (1925, 1932) and RC Desai (1940) that enhancement in state income estimates is possible by reducing wastage ratio of food grains in the state.

\section{Materials and Methods}

\section{Sampling design}

A multi - stage random sampling method was followed to select the ultimate respondent for detailed survey. The lentil crop (Masoor) was taken into Consideration due to area of the crop is pre dominate in the state of Bihar. At the first stage of sampling patna district was selected due to having larger area of the crop across the district of state. After selection of the district, at the second stage of sampling four strata ware formed by combining the contiguous blocks on the same basis like district. The four sampled blocks namely sampatcheck, fatuha, Bihta and Bikram ware selected. At the third stage of sampling, five villages from each starta/block ware randomly selected from the list of villages of the selected blocks. In this way from sampatcheck block, villages namely chipura, chainpur, bahuara, Khushyalchak and baruna were selected. In bihta block the villages namely pannal, kanchanpur, pandepur, jaitipur and gorhanna were selected. In fatuha block villages namely pitambarpur, bikhua, nathupur, gangapur and lasgarichak were selected. In the Bikram block villages namely rahi, bara, mohammadpur, benibigha and baliyari were selected. After full enumeration of lentil growers in the selected villages with consultation of Mukhiya in each village a list was prepared according to their land holding size and classified into three broad categories, using size of holding as small (0.01 to 2.0 ha ) medium ( 2.01 to 4.0 ha ) and large more than $4.01 \mathrm{ha}$. In each village farmers belonging to above three categories i.e. small, medium and large categorized separately. In all 20 sampled 
villages, 2440 farmers were found cultivating lentil crop. Out of the total lentil growers 300 growers were selected From 5 villages multiplied by 15 selected respondents from three categories with multiplied by 4 blocks. The reference year for the study was agricultural year 2004-05. The details of selected farmers were small categories 203, medium categories 73 , and large categories 24.

\section{Results and Discussion}

\section{Pulse crop (Lentil)}

The details of size class wise distribution of farmers with average size of holding ware worked out and presented under table 1 .

The above table reveals that distribution of farmers across the farm. As per the data in all sampled villages there were 1644 small categories of farmers followed by medium categories 592 and large categories 204. The average size of land holding was 1.22 ha was worked out for small categories 2.87 ha for medium categories and 6.96 ha for large categories and average holding size was 2.10 ha. Out of the total number of small farmers in the selected villages, 203 were selected from small categories, 73 were from medium categories and 24 from large categories. In this way a total number of 300 households were form the sample size of the study. The selected household, average holding of small farm was 1.16 ha. Medium farm 2.77 ha, large farm 6.92 ha and average of the all farm was 2.01 ha. Out of the total average farm holding, net cultivated area for small categories 1.03 ha, medium categories 2.69 ha, large categories 6.78 ha and average was 1.89 ha. The gross cropped area in small farm was 1.84 ha, medium farm 4.68 ha, large farm 11.93 ha and overall average was 3.39 ha. The analysis concludes that the size of farm found varies with variation of farms and none of the respondent farmers were found to lease out their cultivated farm.

Use of agricultural land for lentil cultivation

The class size wise distribution of agricultural land for lentil crop in the study area presented under table 2 .

The above table showed that out the total 1071.56 ha of land under the lentil crop 795.39 ha was irrigated and 276.17 was unirrigated. The sampled farmers were reported that the area under irrigation of lentil crop was due to availability of assure irrigation through tube well and gross cropped area mostly under irrigation condition.

\section{Production and productivity of lentil crop}

The survey data related to production and productivity of the crop were collected and arranged under the table 3 .

The table stated above reveals that at overall level 962.06 quintal of lentil (masoor) produced by the sampled farmers with an average productivity of $897.81 \mathrm{~kg}$ per hectare. The productivity across the farm size found varied with variation of farm size. The highest average productivity was recorded in case of large farm $916.39 \mathrm{~kg}$ per ha followed by medium $892.23 \mathrm{~kg}$ per ha and small $889.38 \mathrm{~kg}$ per ha. The gross value of the produce was worked out Rs 1486382.70 at the farm harvest price during the season 2006-07. The productivity was found higher in large farm due to higher uses of inputs in their field.

\section{Utilization of lentil grains}

\section{Seed}

It was reported by the farmers that improved variety of the crop was used in very limited areas and the non-hybrid seeds of lentil covered larger area. The farmers reported that they had been using indigenous seeds of lentil 
since long time in their farms. Some of the farmers were aware about replacement of improved variety of lentil seeds in every four years.

The farmers were share the experience of improved or home saved seeds and reported that after change of HYVs seed they got higher returns whereas farmer who not replace and uses old seeds, obtained low returns. The majority of farmers were reported that due to non-availability of quality seeds at the local level they have used old and home saved seeds or previous years seeds. The farmers who used improved seeds in their field purchased from reputed farmers not from shop and private trades. As per the statistical data during the year 2005-06 only 0.09 lakh quintal HYVS of lentil seeds ware used in the state.

The method of lentil seeds sowing was reported by the farmers through the broadcasting method and row sowing. The seed rate in both methods was on an average 30 to $50 \mathrm{~kg}$ per hectare as reported by the sampled farmers. The varieties which was commonly used in the study area was T-44, Ps-15, 59 and jaul ahar-45.

\section{Seed requirement}

The size class wise of total seed requirements for lentil crop was worked out and presented under the table 4 . Table 4 stated above showed that on an average about 9.42 percent of the produced lentil were used as seed and 13.13 percent kept as seed for future use. The percentage of used seed and kept seed found varied across the farm. Higher the farm lower the retention and vice versa.

\section{Production and disposal of lentil crop in the study area}

The per farm production and disposal of lentil crop was worked out and presented in table 5 . It may be observed from the above table that the marketable surplus found varied with variation of farm size. The marketable surplus worked out for small farm was $279.37 \mathrm{~kg}$, for medium farm $1243.12 \mathrm{~kg}$ and large farm $4531.52 \mathrm{~kg}$. The overall marketable surplus was $864.04 \mathrm{~kg}$ per farm. The percentage of marketable surplus was found higher 71.46 percent in large farm followed by medium farm 50.30 percent and small farm 27.08 percent. The overall marketable surplus was 46.91 percent per farm. It is clearly indicates that almost half of the produce at overall level was retain as home and other purposes. About 46.91 percent of the total produce was marketable surplus. At overall level more than 14.0 percent of the produce used as seed and feed by the farm.

\section{Wastage in regard to lentil crop}

The wastage of pulses crop (lentil) were worked out at various stages and presented under table 6.

The above table 6 revels that in case of all farm class the wastage at harvest level were highest followed by transportation. In other stage almost similar picture of wastage were observed. In case of large farm wastage was 5.21 percent followed by small and medium farm 4.96 percent for each categories and overall wastage was 5.02 percent. The level of wastage higher in harvesting and transportation was may be due to low mechanical method applied and poor road and transportation facility in the area. The wastage during threshing is found minimum in a small farms and higher in large farms mainly due to proper care taken by small farms.

The above table 7 clearly reveals that the retention of seed by all farm groups were found higher and it was estimated for small farm 14.84, medium farm 13.18 percent, large farm 10.70 percent and at the overall level 13.15 percent. The wastage at different stages of production and were found higher in case of 
large farm 5.21 percent and medium and small farm 4.96 percent each farm the overall level was 5.02 percent. In case of feed medium farm wastage were higher 1.80 percent followed by large 1.67 percent and small 0.85 percent. The overall feed wastage was worked out 1.39 percent. Overall level picture showed that 19.56 percent total wastage the farm size wastage percent was found varied with variation of farm smaller the farm higher the wastage rate and lager the farm lower the wastage rate. The overall analysis indicate that a considerable wastage percentage about 19.56 of the total produce were goes wastage through seed, feed and different stages of production. Thus it showed that a good quantum of lentil crop wastage. In all the three sampled farms it was observed that a common tendency of keeping highest quantum as seed were observed it may be due to they were giving top priority of seed retention due to less capacity of purchasing it from the market. It was also observed during the study that no extra irrigation was needed for growing lentil crop even in Rabi season, so a large number of small categories farm were found cultivating the crop and in this way highest percentage of seed used by them. The overall conclusion is that out of the total production of lentil crop in the sampled area only 80.44 percent available for human consumption.

Table.1 Distribution of sampled farmers in the selected areas

\begin{tabular}{|c|c|c|c|c|c|c|}
\hline $\begin{array}{ll}\text { Holding } & \text { size } \\
\text { categories } & \end{array}$ & $\begin{array}{l}\text { No. of } \\
\text { farmer in } \\
\text { the village }\end{array}$ & $\begin{array}{l}\text { Average } \\
\text { size of } \\
\text { holding } \\
\text { (ha) }\end{array}$ & $\begin{array}{l}\text { No. of } \\
\text { sample } \\
\text { farmers } \\
\text { selected }\end{array}$ & 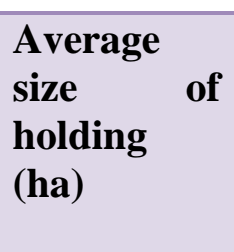 & $\begin{array}{l}\text { Average } \\
\text { net } \\
\text { cropped } \\
\text { area per } \\
\text { HH(ha) }\end{array}$ & $\begin{array}{l}\text { Average gross } \\
\text { cropped area } \\
\text { per } \mathrm{HH}(\mathrm{ha})\end{array}$ \\
\hline Small categories & 1644 & 1.22 & 203 & 1.16 & 1.03 & 1.84 \\
\hline Medium categories & 592 & 2.87 & 73 & 2.77 & 2.69 & 4.68 \\
\hline Large categories & 204 & 6.96 & 24 & 6.92 & 6.78 & 11.93 \\
\hline All categories & 2440 & 2.10 & 300 & 2.01 & 1.89 & 3.39 \\
\hline
\end{tabular}

Table.2 Distribution of agricultural land for lentil crop is study areas.

\begin{tabular}{|l|l|l|l|}
\hline Size of holding & Irrigated (ha) & Un irrigated (ha) & Total \\
\hline Small & 298.50 & 123.21 & 421.71 \\
\hline Medium & 261.13 & 93.21 & 354.34 \\
\hline large & 235.77 & 59.75 & 295.51 \\
\hline All & 795.39 & 276.17 & 1071.56 \\
\hline
\end{tabular}

Table.3 Production and productivity of lentil crop.

\begin{tabular}{|c|c|c|c|}
\hline $\begin{array}{l}\text { Categories of } \\
\text { farm }\end{array}$ & $\begin{array}{l}\text { Production } \\
\text { (Qtls ) }\end{array}$ & $\begin{array}{l}\text { Productivity } \\
\text { in } \mathrm{kg} / \mathrm{ha}\end{array}$ & $\begin{array}{l}\text { Gross value at the farm } \\
\text { harvest price }(R s)\end{array}$ \\
\hline Small & 375.06 & 889.38 & 579467.70 \\
\hline Medium & 316.15 & 892.23 & 488451.75 \\
\hline Large & 270.85 & 916.39 & 418463.25 \\
\hline All & 962.06 & 897.81 & 1486382.70 \\
\hline
\end{tabular}

Note - Value Rs 1545/quintal 
Table.4 Seed requirement for lentil crop

\begin{tabular}{|l|l|l|l|l|l|l|}
\hline $\begin{array}{l}\text { Size } \\
\text { holding }\end{array}$ & $\begin{array}{l}\text { Area } \\
\text { (ha) }\end{array}$ & $\begin{array}{l}\text { Production } \\
\text { Qtl. }\end{array}$ & \multicolumn{2}{|l|}{ Quantity of seed (kg) } & \multicolumn{2}{l|}{ Percentage of production } \\
\cline { 5 - 7 } Small & 421.71 & 375.06 & 35967 & 55658 & 9.59 & 14.84 \\
\hline Medium & 354.34 & 316.15 & 30255 & 41668 & 9.57 & 13.18 \\
\hline Large & 295.51 & 270.85 & 24399 & 28975 & 9.01 & 10.70 \\
\hline Overall & 1071.56 & 962.06 & 90621 & 126301 & 9.42 & 13.13 \\
\hline
\end{tabular}

Table.5 Production and disposal of pulse (lentil)

\begin{tabular}{|c|c|c|c|c|c|c|c|c|c|}
\hline $\begin{array}{l}\text { Holding } \\
\text { size }\end{array}$ & $\begin{array}{l}\text { Avg. } \\
\text { area } \\
\text { (ha) }\end{array}$ & $\begin{array}{l}\text { Productio } \\
\text { in kg }\end{array}$ & $\begin{array}{l}\text { Kept seed of } \\
\text { next time in } \\
\mathrm{kg}\end{array}$ & $\begin{array}{c}\text { Home } \\
\text { consumption } \\
(\mathrm{kg})\end{array}$ & $\begin{array}{c}\text { Kind } \\
\text { wages to } \\
\text { labour (kg) }\end{array}$ & $\begin{array}{l}\text { Marketable } \\
\text { surplus (kg) }\end{array}$ & $\begin{array}{c}\text { Markete } \\
\text { surplus } \\
(\mathrm{kg})\end{array}$ & $\begin{array}{c}\text { d Used as } \\
\text { animal feed } \\
(\mathrm{kg})\end{array}$ & $\begin{array}{l}\text { Previous } \\
\text { year seed } \\
\text { left }(\mathrm{kg})\end{array}$ \\
\hline Small & 1.16 & 1031.68 & $\begin{array}{l}153.10 \\
(14.84)\end{array}$ & $\begin{array}{l}571.55 \\
(55.40)\end{array}$ & $\begin{array}{l}0 \\
(0.0)\end{array}$ & $\begin{array}{l}279.37 \\
(27.08)\end{array}$ & $\begin{array}{l}18.67 \\
(1.81)\end{array}$ & $\begin{array}{l}8.77 \\
(0.85)\end{array}$ & 98.93 \\
\hline Medium & 2.77 & 2471.42 & $\begin{array}{l}325.73 \\
(13.18)\end{array}$ & $\begin{array}{l}683.84 \\
(27.67)\end{array}$ & $\begin{array}{l}22.73 \\
(0.92)\end{array}$ & $\begin{array}{l}1243.12 \\
(50.30)\end{array}$ & $\begin{array}{l}150.75 \\
(6.10)\end{array}$ & $\begin{array}{l}44.48 \\
(1.80)\end{array}$ & 236.51 \\
\hline Large & 6.92 & 6341.34 & $\begin{array}{l}678.52 \\
(10.70)\end{array}$ & $\begin{array}{l}613.46 \\
(9.68)\end{array}$ & $\begin{array}{l}143.94 \\
(2.27)\end{array}$ & $\begin{array}{l}4531.52 \\
(71.46)\end{array}$ & $\begin{array}{l}265.70 \\
(4.19)\end{array}$ & $\begin{array}{l}105.90 \\
(1.67)\end{array}$ & 571.35 \\
\hline Overall & 2.01 & 1841.922 & $\begin{array}{l}242.21 \\
(13.15)\end{array}$ & $\begin{array}{l}621.46 \\
(33.74)\end{array}$ & $\begin{array}{l}17.12 \\
(0.93)\end{array}$ & $\begin{array}{l}864.04 \\
(46.91)\end{array}$ & $\begin{array}{l}70.91 \\
(3.85)\end{array}$ & $\begin{array}{l}25.60 \\
(1.39)\end{array}$ & 173.50 \\
\hline
\end{tabular}

Note: parenthesis indicates percentage

Table.6 Wastage of pulse crop (lentil) at different stages

\begin{tabular}{|c|c|c|c|c|c|c|c|c|c|}
\hline $\begin{array}{c}\text { Holding } \\
\text { size }\end{array}$ & $\begin{array}{c}\text { Production } \\
(\mathbf{k g})\end{array}$ & $\begin{array}{c}\text { Harvesting } \\
\text { stage }\end{array}$ & $\begin{array}{c}\text { Threshing \& } \\
\text { cleaning } \\
\text { stage }\end{array}$ & $\begin{array}{c}\text { At straw } \\
\text { retain }\end{array}$ & $\begin{array}{c}\text { Transpor } \\
\text { tation }\end{array}$ & Storage & $\begin{array}{c}\text { Left in } \\
\text { animal } \\
\text { feed }\end{array}$ & $\begin{array}{c}\text { Wastage in } \\
\text { home } \\
\text { consumption }\end{array}$ & Total \\
\hline Small & 209431 & 3937 & 1068 & 1989 & 2283 & 586 & 42 & 482 & 4.96 \\
& & $(1.88)$ & $(0.51)$ & $(0.95)$ & $(1.09)$ & $(0.28)$ & $(0.02)$ & $(0.23)$ & \\
\hline Medium & 180414 & 3428 & 1028 & 1732 & 1731 & 541 & 54 & 433 & 4.96 \\
& & $(1.900$ & $(0.57)$ & $(0.96)$ & $(0.96)$ & $(0.30)$ & $(0.03)$ & $(0.24)$ & \\
\hline Large & 152192 & 2679 & 1065 & 1567 & 1522 & 639 & 58 & 396 & 5.21 \\
& & $(1.76)$ & $(0.70)$ & $(1.03)$ & $(1.00)$ & $(0.42)$ & $(0.04)$ & $(0.26)$ & \\
\hline All & 542037 & 10044 & 3161 & 5258 & 5529 & 1789 & 190 & 1301 & 5.02 \\
& & $(1.85)$ & $(0.58)$ & $(0.97)$ & $(1.02)$ & $(0.33)$ & $(0.03)$ & $(0.24)$ & \\
\hline
\end{tabular}


Table.7 total wastage of pulse (lentil) in seed, feed and wastage (\%)

\begin{tabular}{|l|c|c|c|c|}
\hline Farm categories & Seed & Feed & Wastage at different stages & Total wastage \\
\hline Small & 14.84 & 0.85 & 4.96 & 20.65 \\
\hline Medium & 13.18 & 1.80 & 4.96 & 19.94 \\
\hline Large & 10.70 & 1.67 & 5.21 & 17.58 \\
\hline All & 13.15 & 1.39 & 5.02 & 19.56 \\
\hline
\end{tabular}

In conclusion, the survey showed that the highest number of farmers in selected area were small categories 185 followed by medium 72 and large 43 . The total number of sampled farmers was 300 . The overall size of holding was 2.01 hectare which is found varied from 6.92 ha of large farm to $1.16 \mathrm{ha}$ small farms. The overall productivity of lentil crop was $897.81 \mathrm{~kg}$ per ha and it found varied with $916.39 \mathrm{~kg} / \mathrm{ha}$ in large farm to $889.38 \mathrm{~kg}$ per ha in small farm. The analysis concludes that at the overall level 9.42 percent of the total produce used as seed and 13.13 percent kept for next season for seed by the farmers. At the overall level 46.91 percent of the total produce was worked out as marketable surplus per farm. At the overall level about 19.56 percent of the total produce goes wastage on the bases of above discussion it may concluded that the wastage percentage were found higher across the farm and suggested that the net availability of crop may be increase through proper management of seed, feed and wastage in the study area.

\section{References}

Ahuja, D.L and K.K Tyagi (2000) estimation of seed, feed and wastages ratios for food grains, Indian journal of agricultural statistics, paper presented in $54^{\text {th }}$ annual conference of ISAS, NDUAT, Kumarganj, Faridabad (UP) during $28^{\text {th }}-30^{\text {th }}$ Nov. 2000.

Ramaswamy, C, and selveraj KN (2002) estimated loss in pulses. Indian journal of agricultural economics, 57(3): (July - Sept. 2002).

Census of India, 2011, New Delhi.

Central statistical organization, GOI, New Delhi.

Desh Pande, R.S. and Singh, D (2001) long term storage structure in pulses, national symposium on pulses for sustainable agriculture and nutrition security, Indian institute of pulses research, New Delhi, April 17-19 2001.

Directorate of statistics and evaluation government of Bihar.

Economics survey 2013 to 2016 Department of finance, Govt. of Bihar.

Gill, P.P.S (2000) wasted grains enough for seventy millions, the tribune, Chandigarh, 13(20): 4.

Ojha, T.P. (1984) "improved post harvest technology to maximize field and minimize quantitative and qualitative losses" - post harvester technology center. IIT Khargpur.

\section{How to cite this article:}

Amalendu Kumar and Singh, R.S. 2019. Estimated Status of Quantum Losses other than Consumption under Seed, Feed and Wastage: Farm Levels Study of Pulse (Lentil) in Bihar. Int.J.Curr.Microbiol.App.Sci. 8(03): 1865-1872. doi: https://doi.org/10.20546/ijcmas.2019.803.221 